\title{
Prospects of the Application of Garlic Extracts and Selenium and Silicon Compounds for Plant Protection against Herbivorous Pests: A Review
}

\author{
Nadezhda Golubkina ${ }^{1, *}$, Vladimir Zayachkovsky ${ }^{1}$, Sergei Sheshnitsan ${ }^{2}$, Liubov Skrypnik ${ }^{3}(\mathbb{D}$, \\ Marina Antoshkina ${ }^{1}$, Anna Smirnova ${ }^{1}$, Mikhail Fedotov ${ }^{4}\left(\mathbb{D}\right.$ and Gianluca Caruso ${ }^{5}$
}

1 Analytical Laboratory Department, Federal Scientific Vegetable Center, 143072 Moscow, Russia; vladimir89854217114@mail.ru (V.Z.); limont_m@mail.ru (M.A.); annasmirnova28@yandex.ru (A.S.)

2 Department of Landscape Architecture and Soil Science, Voronezh State University of Forestry and Technologies, 394036 Voronezh, Russia; sagittarius-18_8@mail.ru

3 Institute of Living Systems, Immanuel Kant Baltic Federal University, 236040 Kaliningrad, Russia; LSkrypnik@kantiana.ru

4 Laboratory of New Metallurgical Processes, A. Baikov Institute of Metallurgy and Material Science, 119334 Moscow, Russia; Mikle_fed@mail.ru

5 Department of Agricultural Sciences, University of Naples Federico II, 80055 Portici, Italy; gcaruso@unina.it

* Correspondence: segolubkina@rambler.ru; Tel.: +7-903-118-50-30

check for updates

Citation: Golubkina, N.; Zayachkovsky, V.; Sheshnitsan, S.; Skrypnik, L.; Antoshkina, M.; Smirnova, A.; Fedotov, M.; Caruso, G. Prospects of the Application of Garlic Extracts and Selenium and Silicon Compounds for Plant Protection against Herbivorous Pests: A Review. Agriculture 2022, 12, 64

https://doi.org/10.3390/

agriculture12010064

Academic Editors: Fernanda Fidalgo and Conceição Santos

Received: 27 November 2021

Accepted: 31 December 2021

Published: 5 January 2022

Publisher's Note: MDPI stays neutral with regard to jurisdictional claims in published maps and institutional affiliations.

Copyright: (c) 2022 by the authors. Licensee MDPI, Basel, Switzerland. This article is an open access article distributed under the terms and conditions of the Creative Commons Attribution (CC BY) license (https:/ / creativecommons.org/licenses/by/ $4.0 /)$.

\begin{abstract}
Protection of plants against herbivorous pests is an important aspect that guarantees agricultural efficiency, i.e., food provision to populations. Environmental, water and foodstuff pollution by toxic pesticides, along with climate changes, highlight the necessity to achieve intensive development of ecologically safe methods of herbivory control. This review discusses modern methods of plant protection against insect pests: the biofortification of plants with selenium, treatment of plants with bulk and nano-silicon, and utilization of garlic extracts. The peculiarities of such methods of defense are described in relation to growth stimulation as well as increasing the yield and nutritional value of products. Direct defense methods, i.e., mechanical, hormonal, through secondary metabolites and/or mineral element accumulation, and indirect defense via predator attraction are discussed. Examples of herbivorous pest control during plant growth and grain/seed storage are emphasized. A comparison of sodium selenate, silicon containing fertilizer (Siliplant) and garlic extract efficiency is analyzed on Raphanus sativus var. lobo infested with the cruciferous gall midge Contarinia nasturtii, indicating the quick annihilation of pests as a result of the foliar application of garlic extract or silicon-containing fertilizer, Siliplant.
\end{abstract}

Keywords: herbivory; selenium; silicon; garlic extracts

\section{Introduction}

Approximately $40 \%$ of crop harvest is lost every year due to herbivory attacks, diseases, weeds and grain infestation [1-3]. Insect pests are known not only to decrease plant growth and development, causing crop death in extreme cases, but also to act as vectors of pathogens [4]. These facts result not only in great economical losses but also stimulate insecticide production, thus increasing the pollution of the environment, water and food products with toxic compounds. At present, worldwide insecticide production reaches more than 3 million tons per year. Russian statistics reveal that, during 2016-2020, the production of these compounds increased by 1.8 times and reached 131 thousand tons. Taking into account that insect activity is directly affected by temperature as they are poikilothermic organisms, a temperature increase will induce increased herbivory occurrence in agricultural crops in the near future, a phenomenon connected with the increase in reproduction, survival and geographical expansion $[5,6]$. These facts highlight the urgent necessity to revise the existing methods of pest control, abandon the utilization of chemical 
insecticides and develop new, safe and highly efficient methods of plant protection against herbivory [7]. In this respect, the utilization of environmentally friendly pesticides, such as essential oils, plant extracts, special microelements demonstrating growth stimulation effects and inert powders, may become the main method of herbivory control.

To be successful against herbivorous pests, natural plant defense should be encouraged, in order to develop ecologically safe and highly efficient methods of crop protection (Figure 1) $[4,8,9]$. Apart from mimicry (mimosa) and endophytes (mutualistic fungi), four approaches may be enhanced artificially: (1) mechanical protection, (2) mineral elements' hyperaccumulation, (3) increase in secondary metabolite production and (4) predator attraction. Taking these facts into consideration, we have chosen three topics to develop in this review: (i) the biofortification of plants with selenium, (ii) the utilization of an ionic form of silicon and its nanoparticles and (iii) garlic extracts. The last method was first described many years ago, whereas the utilization of Se and Si should be considered as one of the latest extremely promising approaches to solving this problem. Although neither of the mentioned methods has gained profound attention from commercial companies thus far, such ecofriendly and highly efficient supplements, which also show growth stimulation effects and the ability to protect plants against other biotic and abiotic stresses, may herald a new era of modern agriculture.

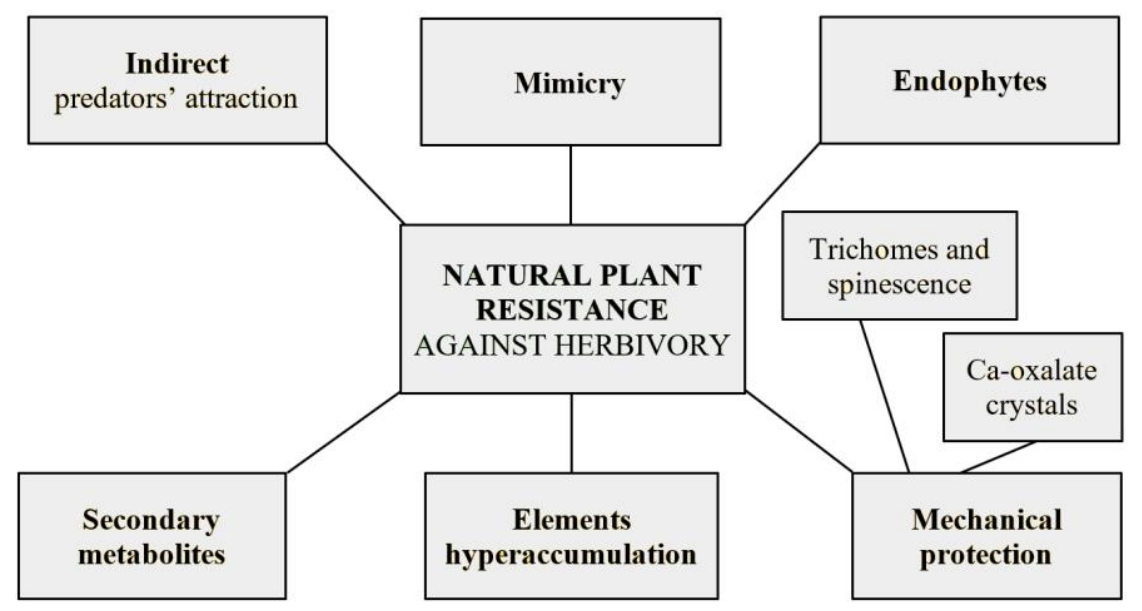

Figure 1. Natural methods of plant resistance against herbivories.

\section{Selenium Compounds}

To date, interest to selenium has mostly been connected with the worldwide problem of this element deficiency and the importance of agricultural crops' biofortification to optimize the human Se status and human immunity [10]. Indeed, besides the well-known, powerful protection of Se against cardiovascular diseases and cancer, valuable antioxidant properties and beneficial effects on human fertility and brain activity [11-13], the latest investigations in China indicated the high potential of Se utilization in COVID-19 prevention. Epidemiological investigations revealed statistically lower levels of COVID-19 morbidity and mortality among the population in Chinese provinces with high Se status [14]. On 11 March 2021, the lowest COVID-19 morbidity among the European population was recorded in Finland, the country where Se consumption levels have been optimized due to the wide utilization of Se-containing fertilizers [15]. On the contrary, Baltic countries, Slovenia and Great Britain, known as Se-deficient countries, demonstrate significantly higher levels of COVID-19 morbidity. Though the abundance of grain import from endemic regions of Canada and the USA with high Se content (500-600 $\mathrm{gg} \mathrm{Kg}^{-1}$ ), the exclusive utilization of wheat cultivars of native origin with relatively low Se levels (approximately $80 \mu \mathrm{g} \mathrm{Kg}^{-1}$ ) in Russia resulted in a decrease in the human Se status [16], which may partially explain the high COVID-19 morbidity in this country. Furthermore, wide Se fertilizer 
utilization in Finland since 1980 led to an outstanding decrease in mortality caused by cancer and cardiovascular diseases among the population [15].

Against this background, the issue of protecting plants from insect pests using Se biofortification draws significantly less attention and, in particular, plant biofortification and reduction in pest attacks are discussed separately.

Situated in the sixth group of the periodic table, Se demonstrates similar properties to sulfur and is included in compounds with different valences: selenates $(+6)$, selenites $(+4)$, nano Se (0), selenides $(-2)$ and organic derivatives [17]. Their toxicity to humans decreases according to: selenites $>$ selenates $>$ organic Se $>$ nano Se. The same sequence of Se toxicity levels is also recorded for plants, while, for insects, only fragmental data are available. The investigations of Jensen et al. [18] on the toxicity of different Se derivatives' chronic application to Megaselia scalaris larvae revealed the lowest $\mathrm{LC}_{50}$ level for SeCys $\left(83 \mu \mathrm{g} \mathrm{g} \mathrm{g}^{-1}\right.$ f.w.), while SeMet, selenate $(+6)$ and selenite $(+4) \mathrm{LC}_{50}$ values were $1.6,3.1$ and 4.7 times higher. Data related to Spodoptera exigue (Hubner) larvae revealed a decrease in $\mathrm{LC}_{50}$ levels from Se-Met and $\mathrm{Se}^{+6}\left(\mathrm{LC}_{50}<50 \mu \mathrm{g} \mathrm{g}^{-1}\right.$ f.w.) to SeCystine ( $\mathrm{LC}_{50} 15 \mu \mathrm{g} \mathrm{g}{ }^{-1}$ f.w.) and Se ${ }^{+4}\left(\mathrm{LC}_{50}\right.$ $9.14 \mu \mathrm{g} \mathrm{g}^{-1}$ f.w) $[19,20]$, which indicate significant species differences regarding diverse chemical forms of Se. Contrary to organic derivatives, the inorganic ones (especially selenates) generally have anti-feedant activity for insects [21]. Insects' inability to avoid organic Se forms results in toxic effects when feeding on Se-supplemented plants $[19,20,22,23]$. As far as Se nanoparticles are concerned, the information is rather scant. Indeed, the joint application of nano-Se and melatonin to wheat seedlings improved plant resistance to aphids via an increase in antioxidant levels and activation of the phenylpropane pathway [24].

Notably, among organic Se forms, methylated Se forms containing amino acids (SeMeSeCys, SeMeSeMet) are the most valuable ones in human society due to their high anticarcinogenic activity [25]. In plants and insects, the formation of methylated forms may be considered a protection against Se toxicity. Indeed, such derivatives usually accumulate in the flowers of Se hyperaccumulators and a few herbivories are able to tolerate high Se levels $[26,27]$. On the contrary, non-Se-accumulator plants concentrate Se predominantly in the leaves, either as inorganic forms or as Se-containing amino acids and proteins, with a much lower content of amino acids in methylated forms [28]. Volatile chemical forms of selenium are di- and tri-methyl selenides, which deter herbivories [29]. Observations of selenate supplementation to herbivories indicate both toxic and repelling effects [30]. The latter phenomenon was described on Se hyperaccumulator Stanlea piñata (447 $\mathrm{mg} \mathrm{Se} \mathrm{Kg}^{-1}$ d.w.) and secondary Se accumulator Indian mustard (230 $\mathrm{mg} \mathrm{Se} \mathrm{Kg}^{-1}$ d.w.) under Mizus persicae (larvae) [31], Pieris rapae (larvae) [32] and grasshopper and cricket infestation (adults) [33]. Se may decrease herbivories' survival and mobility and increase the duration of the immature stage of insect development.

Selenium may repel herbivories, slow down growth or cause toxicity, thus increasing plants' growth. The list of target insects under Se supplementation is rather large and includes weevils, aphids, white cabbage butterfly, beetles and caterpillars (Figure 2) [34,35]. Investigations of Prins on S. pinnata [36] revealed a protective effect of Se against nematodes. Broccoli supplemented with sodium selenate $\left(50 \mathrm{mg} \mathrm{L}^{-1}\right)$ demonstrated anti-feedant properties towards Delia radicum larvae, which decreased thrice the survival of pupae [37]. In another observation, genetically modified potatoes stable against Colorado beetles contained extremely high levels of selenium in leaves without any artificial Se biofortification (approximately $1 \mathrm{mg} \mathrm{Kg}{ }^{-1}$ d.w.) [38]. It is well known that grain with high selenium content is less damaged by pests during storage [35].

The repelling and toxic effects of Se compounds are recorded for herbivories of different taste preferences, such as cell disrupters and phloem and leaf feeders, which is extremely valuable in field conditions, where plants are subjected to numerous herbivory species $[22,31-33,39,40]$. The intensity of the beneficial effect of such treatment is closely connected to the Se dose applied. Indeed, selenium-biofortified B. napus plants with high Se concentrations $\left(>800 \mathrm{mg} \mathrm{Kg}^{-1}\right.$ ) were less infected with a turnip aphid herbivory compared to plants with low Se levels $\left(<100 \mathrm{mg} \mathrm{Kg}^{-1}\right)$, while feeding by red legged mites was reduced 
by $200 \%$ in selenium-biofortified plants [41]. In general, the Se dose should be adopted experimentally, taking into consideration the significant differences in resistance to high Se doses in both different plants and herbivory species. Indeed, according to literature data, aphids are more sensitive to Se than spider mint [32,40].

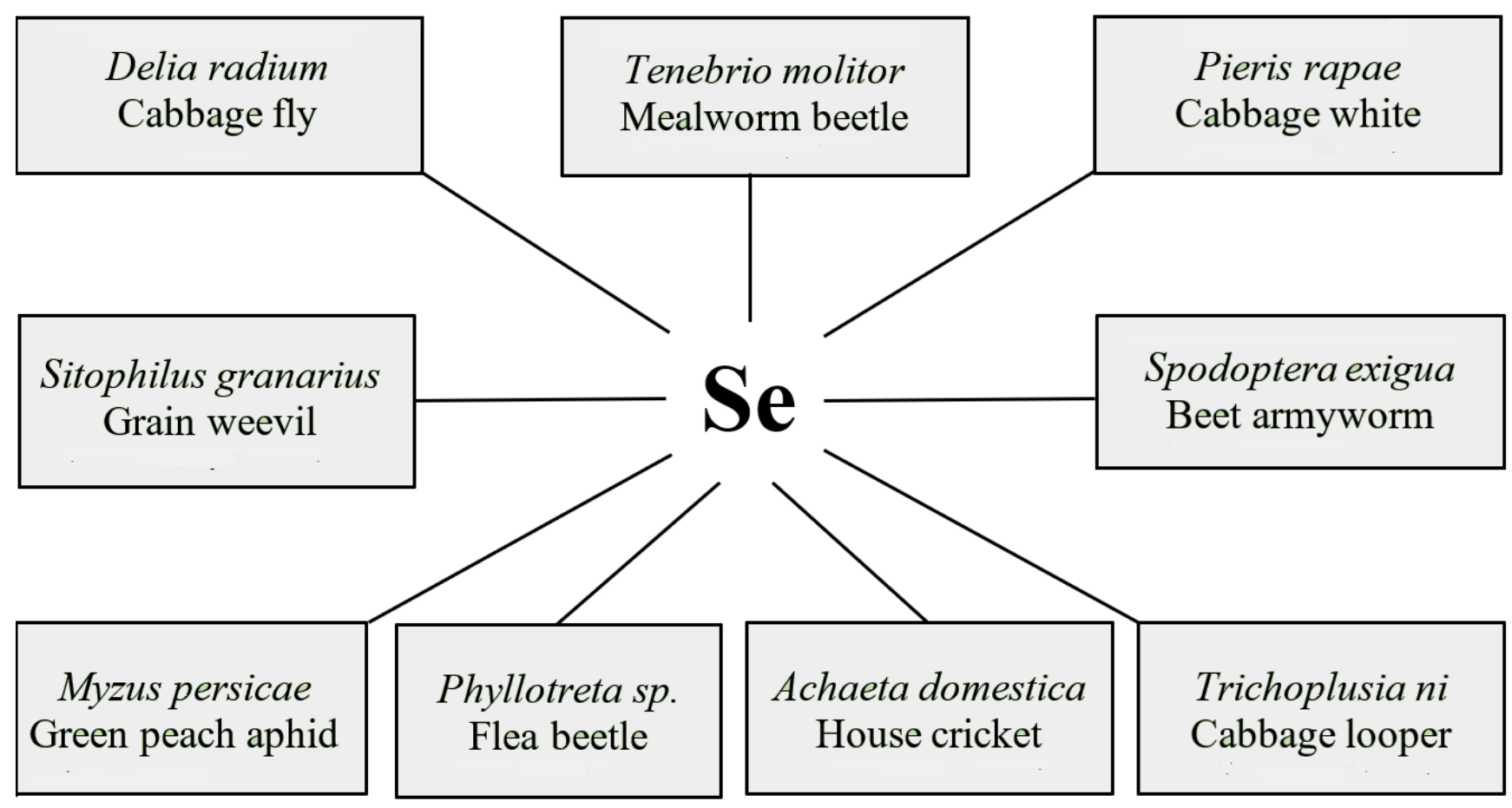

Figure 2. Examples of plant protection against herbivory using selenium [19,22,31-33,37,42-44].

Honey from seleniferous areas contains significant amounts of Se $\left(0.4-1 \mu \mathrm{g} \mathrm{Se} \mathrm{g}^{-1}\right)$, thus becoming a truly functional product enriched with microelements [32,45], though chronic exposure of bees to high Se levels may result in growth retardation and death [46].

\section{Silicon}

Similarly to $\mathrm{Se}, \mathrm{Si}$ is not an essential element to plants and its growth stimulation properties are connected to its protective role under conditions of biotic and abiotic stress [47-51]. Its accumulation in plants is governed by soil characteristics, water availability and plants' evapotranspiration [52] and may vary considerably between $\mathrm{Si}$ accumulators (predominantly representatives of the Poaceae family, with Si concentration up to $10 \%$ per d.w.), intermediates (Brassicaceae, Fabaceae representatives, less than 1\% content) and excluders (for instance, tomato plants).

Silicon provides plant protection against herbivories, improving morphological, biochemical and molecular protection and decreasing plant tissue disruption, insects' growth intensity and survival. This element causes significant biochemical changes in plants, activating the biosynthesis of photosynthetic pigments and increasing antioxidants, antistress proteins and phytohormone production [53]. The attraction of natural predators and parasitoids during a pest attack as a result of $\mathrm{Si}$ supplementation is caused by the emission of herbivore-induced plant volatiles, whose amounts increase in Si-treated plants [47]. Stimulation of plant hormone biosynthesis is considered the most pronounced effect of $\mathrm{Si}$, inducing ethylene, salicylic and jasmonic acid production [52].

Silicon supplementation stimulates the additional formation of trichomes and wax accumulation on the surfaces of leaves, and it strengthens cell walls by improving lignin biosynthesis (Figure 3). Thus, while plant protection against herbivory pests by Se compounds takes place by direct (toxicity of Se derivatives applied) and indirect action (plants' 
Se accumulation and emission of toxic volatiles), Si provides valuable protection of plants exclusively by changing plants' physical and biochemical characteristics.

Both ionic forms of Si and Si nanoparticles demonstrate protective effects against biotic stresses in the case of soil and foliar Si supplementation [47,53-59] and, in particular, inducing the production of herbivory-induced plant volatiles attracting predators [57]. Despite rather restricted reports on the nano Si effect on herbivories, it is supposed that the small size of nanoparticles promotes their penetration through cuticle layers, blocking feed digestion and causing changes in morphology. Numerous publications devoted to Si application have focused on the prospects of this approach, particularly the possibility to improve the growth and development of agricultural crops and increase yields. To date, some investigations have proven the ability of Si to increase plants' resistance to the attacks of different herbivory species: Lepidoptera (butterflies and moths) [50], Hemiptera (true bugs, such as cicadas, aphids, planthoppers) [51,60], Diptera (true flies) [61], Thysanoptera (thrips) [62] and others [44].

Several examples of silicon protection are presented below (Figure 3) [63].

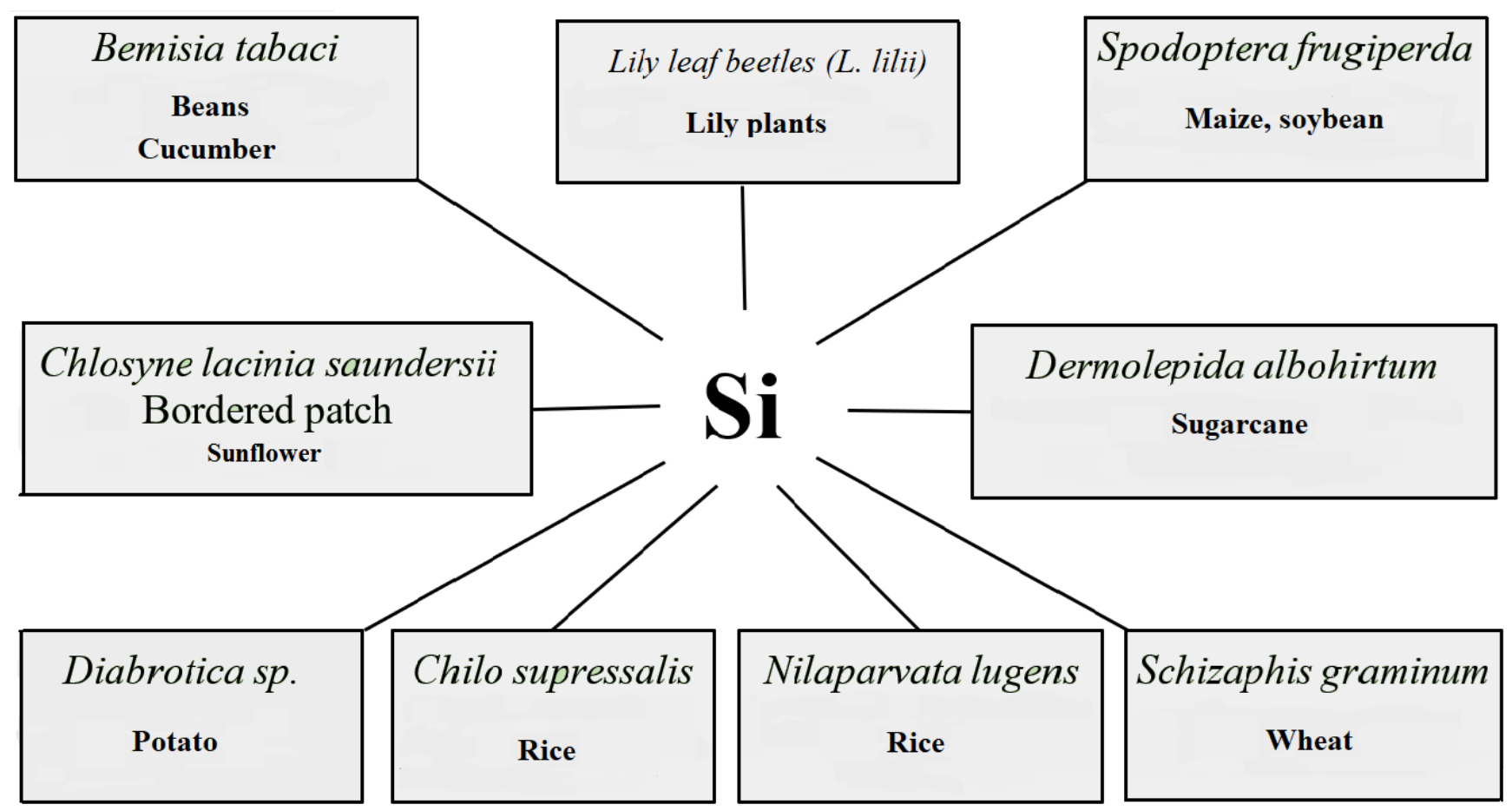

Figure 3. Si application against herbivory pests [64-74].

Among these examples, it is worth noting the three-fold decrease in Bemisia tabaci oviposition as a result of $1 \%$ silicic acid foliar application on bean and cucumber plants $[64,65]$; the intensive development of trichomes with high Si content under 1\% silicic acid supply, leading to Spodoptera frugiperda larvae mortality in tomatoes, soybean and maize [67]; the possibility of AMF to increase root Si content, causing increased cane beetle larvae mortality [69]; the protective effect of wheat against Schizaphis graminum [73,74] and the significant protective effect of granite dust against lily leaf beetle [66]. It is significant that Si's beneficial effect takes place both in plant accumulators of Si and in Si excluders [67].

The information shown in Figure 3 indicates that Si may be effective for the protection of both vegetating plants and grain under storage.

\section{Garlic Extracts}

Garlic (Allium sativum L.) is one of the most valuable vegetables, in terms of outstanding health-promoting activity, including anti-tumor, cardio-protective, anti-microbial and 
anti-diabetic effects [75], high antioxidant activity (vitamins, polyphenols, flavonoids) and significant amounts of sulfur-containing derivatives [76]. It is known to possess growth stimulation properties and the ability to protect plants against pathogens [77]. In practice, the harvesting, storage and processing of garlic are usually accompanied by the formation of wastes, including partially damaged cloves, whose utilization in agriculture as a protection tool against biotic stresses may become highly valuable. The demonstrated insecticidal activity of garlic is determined by allicin, formed as a result of alliinase activity during clove crushing and other sulfur derivatives [78]. Interestingly, attacks by herbivorous pests, pathogens and animals, causing biotic stress, promote allicin biosynthesis [79].

Examples of garlic's protective effect against herbivories, shown in Table 1, indicate the high efficiency of this approach in combating caryopsis, scoop, whitefly, weevils, etc. Furthermore, the investigations of Hardiansyah et al. [80] demonstrated that the foliar supplementation of garlic extract significantly increased rice yield due to the prevention of grain losses connected with scaly finch (Lonchura punctulata) attacks.

Table 1. Examples of garlic utilization against insect attack.

\begin{tabular}{|c|c|c|c|c|}
\hline Insects, Birds & Plant & $\begin{array}{c}\text { Stage of } \\
\text { Development }\end{array}$ & $\mathrm{LC} 50\left(\mathrm{mg} \mathrm{L}^{-1}\right)$ & References \\
\hline \multicolumn{5}{|c|}{ Garlic oil } \\
\hline $\begin{array}{l}\text { Black cutworm } \\
\text { (Agrotis ipsilon) }\end{array}$ & Rice, beet, cotton, blackberry & $\begin{array}{l}\text { Eggs, } \\
\text { Larvae, } \\
\text { Pupae }\end{array}$ & $\begin{array}{c}60 \\
190 \\
90\end{array}$ & [81] \\
\hline Silverleaf whitefly (Benisia tabaci) & $\begin{array}{l}\text { Tomato, cucumber, pumpkin, } \\
\text { cotton, melon, Brassica }\end{array}$ & Imago & 150 & [82] \\
\hline Cacopsylla chinensis & Plum & Imago & 142 & [83] \\
\hline $\begin{array}{c}\text { Cowpea weevil } \\
\text { (Calloso-bruchus maculatus) }\end{array}$ & Vigna chinensis & Imago & 0.25 & [84] \\
\hline $\begin{array}{l}\text { Grasshopper } \\
\text { (Heteracris littoralis) }\end{array}$ & Maize, rice, vegetables, cotton & $\begin{array}{l}\text { First instar } \\
\text { Larvae }\end{array}$ & 670 & [85] \\
\hline Cabbage looper (Trichoplusia ni) & Cabbage & Larvae & 3300 & [86] \\
\hline $\begin{array}{c}\text { Rice weevil } \\
\text { (Sitophilus oryzae) }\end{array}$ & Rice & Imago & 0.017 & [87] \\
\hline \multicolumn{5}{|c|}{ Garlic extracts } \\
\hline $\begin{array}{l}\text { Kelly's citrus thrips (Pezothrips } \\
\text { kellyanus) }\end{array}$ & Citrus & Larvae & $\begin{array}{l}\text { Low protection } \\
\text { level }\end{array}$ & [88] \\
\hline $\begin{array}{c}\text { Cowpea weevil } \\
\text { (Callosobruchus maculatus) }\end{array}$ & Chickpea seeds, Vigna unguiculata & Imago & $0.11 \mathrm{~g} \mathrm{~L}^{-1}$ & [89] \\
\hline $\begin{array}{c}\text { red palm weevil } \\
\text { Rhynchophorus ferrugineus } \\
\text { Diamondback moth (Plutella xylostella), }\end{array}$ & Palms & Larvae & $* 44 \mu \mathrm{g} \mathrm{mL}-1$ & [90] \\
\hline $\begin{array}{l}\text { Cabbage aphid (Brevicoryne brassicae), } \\
\text { Cabbage webworm (Hellula undalis), } \\
\text { Cabbage looper (Trichoplusia ni) }\end{array}$ & Cabbage (Brassica oleracea) & Larvae, imago & $200 \mathrm{~g} \mathrm{~L}^{-1}$ & [91] \\
\hline Coleoptera, Bruchinae & $\begin{array}{l}\text { Prosopis laevigata seeds soaking in } \\
5 \% \text { during } 3 \text { days at } 20^{\circ} \mathrm{C}\end{array}$ & Larvae, imago & & [92] \\
\hline $\begin{array}{l}\text { Spontaneous herbivory attacks in field } \\
\text { conditions }\end{array}$ & Cucurbita pepo ( $1 \%$ water extract) & - & ** & [93] \\
\hline \multicolumn{5}{|c|}{ Garlic juice } \\
\hline Maize weevil (Sitophilus zeamais) & Storage of maize grain & Imago & $\begin{array}{l}90 \% \text { lethal } \\
\text { mortality }\end{array}$ & [94] \\
\hline $\begin{array}{l}\text { Cabbage root fly } \\
\text { (Delium radicum) }\end{array}$ & & $\begin{array}{l}\text { Eggs } \\
\text { Larvae } \\
\text { Imago }\end{array}$ & $\begin{array}{l}0.8 \% \text { (7 days) } \\
6.8 \% \text { (4 days) } \\
0.4 \% \text { ( } 2 \text { days })\end{array}$ & [95] \\
\hline
\end{tabular}


Table 1. Cont.

\begin{tabular}{|c|c|c|c|c|}
\hline Insects, Birds & Plant & $\begin{array}{c}\text { Stage of } \\
\text { Development }\end{array}$ & $\mathrm{LC50}\left(\mathrm{mg} \mathrm{L}^{-1}\right)$ & References \\
\hline $\begin{array}{c}\text { Housefly } \\
\text { (Musca domestica) }\end{array}$ & & $\begin{array}{l}\text { Eggs } \\
\text { Larvae } \\
\text { Imago }\end{array}$ & $\begin{array}{l}1.6 \% \text { (7 days) } \\
4.5 \% \text { (4 days) } \\
2.2 \% \text { ( } 2 \text { days })\end{array}$ & [95] \\
\hline \multicolumn{5}{|c|}{ Diallyl polysulfides } \\
\hline Cacopsylla chinensis & Plum & Imago & $\begin{array}{l}\text { 11.04 DADS } \\
0.640 \text { DATS }\end{array}$ & [83] \\
\hline $\begin{array}{c}\text { Sciarid fly } \\
\text { (Lycoriella ingénue) }\end{array}$ & Mushrooms, herbs & Larvae & $\begin{array}{c}0.25 \text { DAS } \\
0.087 \text { DADS } \\
0.25 \text { DATS }\end{array}$ & [96] \\
\hline $\begin{array}{c}\text { Maize weevil } \\
\text { (Sitophilua zeamais) }\end{array}$ & Maize & Imago & 5.54 DATS & [97] \\
\hline $\begin{array}{l}\text { Red flour beetle } \\
\text { (Tribolium castaneum) }\end{array}$ & Cereals, flour & Imago & 1.02 DATS & \\
\hline
\end{tabular}

DAS—diallyl sulfide; DADS—diallyl disulfide; DATS—diallyl trisulfide [98]; ${ }^{*}$ onion/garlic extract was used; ** yield and photosynthetic pigments increase.

The powerful insecticidal properties of garlic and Allium cepa essential oil have been demonstrated. Furthermore, appropriate information has been recorded for sulfur compounds of these plants, allyl disulfides and allyl mercaptane, in the protection of plants against rice weevil [99]. Allyl mercaptane's insecticidal properties are based on the inhibition of insects' acetylcholine esterase.

Comparison between garlic juice's effects on two insect species, housefly (Musca domestica) and cabbage root fly (Delia radiculus), indicated the importance of the developmental stage and species differences in insects' tolerance [95]. Indeed, the lowest $\mathrm{LD}_{50}$ values were recorded at the egg and adult stages of development, accompanied by significantly higher $\mathrm{LD}_{50}$ values for Musca domestica. The opposite situation was demonstrated for $\mathrm{LD}_{50}$ values at the larvae stage of development (Table 1). In a cowpea seed storage experiment with Callosobruchus maculatus infestation [89], the authors demonstrated lower $\mathrm{LD}_{50}$ values associated to garlic extract $\left(0.11 \mathrm{~g} \mathrm{~L}^{-1}\right)$ than to garlic powder $\left(9.66 \mathrm{~g} \mathrm{Kg}^{-1}\right)$ and emphasized the high potential of garlic extract utilization in the protection of chickpea against this very dangerous herbivory of legumes.

\section{Comparative Evaluation of the Efficiency of Raphanus sativus var. Lobo Protection against Cruciferous Gall Midge (Contariana nastirtii) Using Foliar Application of Selenium, Silicon and Garlic Extract}

Raphanus sativus var. Lobo, or margelan radish, belongs to the cruciferous family and, thanks to the low content of radish oil, demonstrates a pleasant taste. This crop suitably grows in most regions of Russia and is widespread in China and Korea.

Cruciferous gall midge, which lays eggs in inflorescences, causes significant damage to the seed yield of loba, thus preventing seed set.

Gall midges (Diptera: Cecidomyiidae), including more than 6000 species [100], form a large insect family with high speed of species formation compared to other Diptera insects [101]. Most of the gall midge species are herbivorous monophages [100] feeding on a single plant family, plant species or separate parts [102,103]. Most representatives of Contarinia nasturtii (Kieffer, Diptera: Cecidomyiidae) freely live in flower buds or in folded leaves or galls of leaf folds [100,104].

The productivity of lobo seeds is sharply reduced when infected by flower gall midge (Figure 4). 


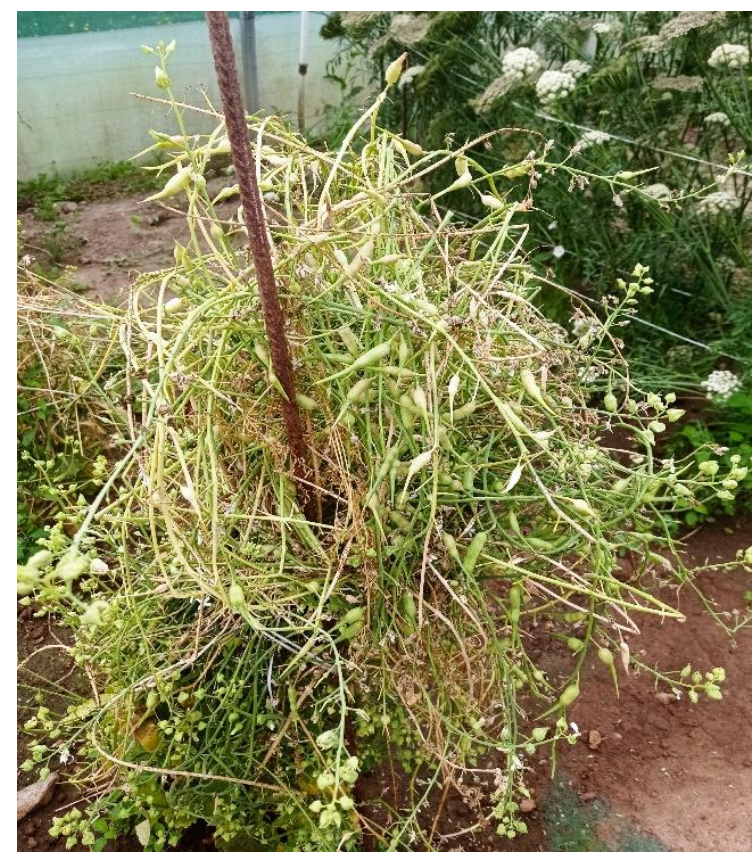

Figure 4. Raphanus sativus var. lobo infested by Contarinia nasturtii.

Single spraying of lobo plants during the period of active gall midge infestation by (a) sodium selenate solution (50 mg L $\left.\mathrm{m}^{-1}\right)$, (b) Siliplant fertilizer as a source of ionic silicon $\left(5 \mathrm{~mL} \mathrm{~L}^{-1}\right)$ and (c) garlic extracts $(5 \%)$ resulted in $100 \%$ larvae mortality only one week later in cases of Siliplant application, either singly or in combination with sodium selenate and garlic extract supplementation. The lack of a significant positive effect of sodium selenate supplementation may be connected both to the lower gall midge sensitivity to Se and/or the necessity for a longer period of exposure.

Among the biochemical parameters tested, a significant disaccharide content increase was recorded under all treatments, especially intensive in the case of garlic extract (Figure 5).

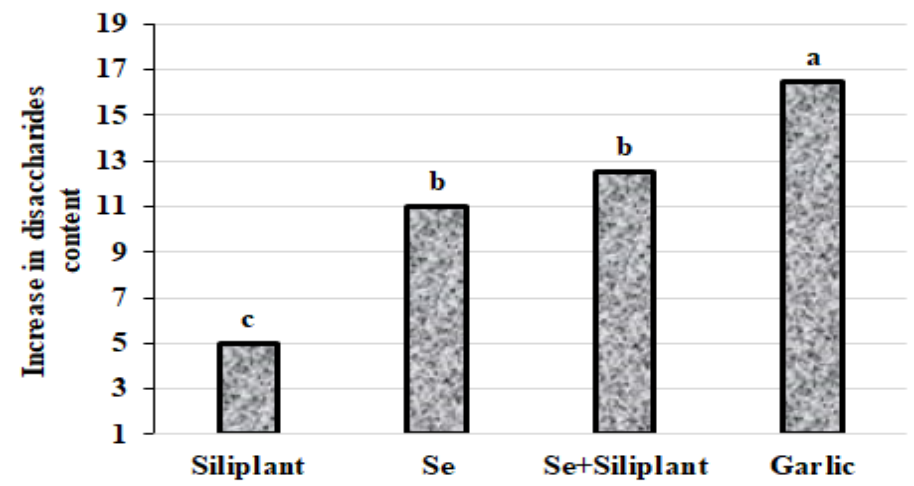

Figure 5. Changes in disaccharide content in Raphanus sativus var. lobo treated with Siliplant, Se and garlic extract.

The detected phenomenon is directly connected with the active participation of carbohydrates in plant protection [105] and may be highly significant for increasing the nutritional value of vegetables.

Other biochemical parameters (Table 2) indicate a statistically significant increase in polyphenol content in lobo upon garlic extract treatment, contrary to sodium selenate application, which demonstrated only a slight tendency to this increase. The detected beneficial effect of garlic extract on phenolic accumulation in lobo (1.22 times compared to control plants) was in agreement with a similar phenomenon described in tomato [106]. 
Table 2. Effect of foliar application of Si (Siliplant), sodium selenate and garlic extract on biochemical characteristics and infestation of Raphanus sativus var. lobo by Contarinia nasturtii.

\begin{tabular}{|c|c|c|c|c|c|}
\hline Parameter & Control & Siliplant & Se & $\begin{array}{c}\text { Se }+ \\
\text { Siliplant }\end{array}$ & Garlic \\
\hline Presence of live larvae & ++ & - & + & - & - \\
\hline Dry matter, $\%$ & $12.29 \mathrm{a}$ & $11.67 \mathrm{a}$ & $11.25 \mathrm{a}$ & $12.48 \mathrm{a}$ & $11.56 \mathrm{a}$ \\
\hline $\mathrm{AOA}^{*}, \mathrm{mg} \mathrm{GAE} \mathrm{g}^{-1}$ d.w. & $46.1 \mathrm{a}$ & $44.1 \mathrm{a}$ & $48.6 \mathrm{a}$ & $46.1 \mathrm{a}$ & $50.5 \mathrm{a}$ \\
\hline $\mathrm{TP}^{* *}, \mathrm{mg} \mathrm{GAE} \mathrm{g}^{-1}$ d.w. & $14.0 \mathrm{~b}$ & $15.0 \mathrm{ab}$ & $16.0 \mathrm{ab}$ & $16.1 \mathrm{ab}$ & $17.1 \mathrm{a}$ \\
\hline Se, $\mu g \mathrm{Kg}^{-1}$ d.w. & $146 \mathrm{~d}$ & $213 c$ & $1080 \mathrm{~b}$ & $1295 a$ & $150 \mathrm{~d}$ \\
\hline Monosaccharides, $\%$ & $17.0 \mathrm{a}$ & $16.9 \mathrm{a}$ & $12.6 b$ & $13.9 b$ & $16.5 \mathrm{a}$ \\
\hline Disaccharides, \% & $0.2 \mathrm{~d}$ & $1.0 \mathrm{c}$ & $2.2 \mathrm{~b}$ & $2.5 b$ & $3.3 \mathrm{a}$ \\
\hline Total sugar, $\%$ & $16.8 \mathrm{bc}$ & $17.9 \mathrm{ab}$ & $14.8 \mathrm{c}$ & $16.4 \mathrm{bc}$ & $19.8 \mathrm{a}$ \\
\hline Water-soluble compounds TDS, $\mathrm{mg} \mathrm{g}^{-1}$ & $57.1 \mathrm{~b}$ & $72.8 \mathrm{a}$ & $70.4 \mathrm{a}$ & $56.3 b$ & $58.0 \mathrm{~b}$ \\
\hline Nitrates, $\mathrm{mg} \mathrm{Kg}^{-1}$ d.w. & $2968 b$ & $3112 \mathrm{ab}$ & $3306 a$ & $2326 c$ & $2750 \mathrm{bc}$ \\
\hline Ash, \% & $10.0 \mathrm{a}$ & $10.9 \mathrm{a}$ & $11.3 a$ & $9.1 \mathrm{a}$ & $9.1 \mathrm{a}$ \\
\hline
\end{tabular}

The lower efficiency of sodium selenate treatment compared to that of Siliplant and garlic extract, and the different intensities in biochemical changes (Table 2, Figure 4) indicate that Se's protective effects require more time than those of $\mathrm{Si}$ and garlic extracts.

\section{Prospects and Constraints of Plant Protection against Herbivory Pests via Se, Si and Garlic Extract Application}

In general, the comparison of Se, $\mathrm{Si}$ and garlic extracts' efficiency against herbivory attack reveals several peculiarities. First, active elements demonstrating significant toxicity to insects are Se in sodium selenate, Si in bulk and nano Si particles and sulfur compounds in garlic extracts. The resulting effect is either toxicity or repellent activity. In all living organisms, Se may substitute $S$ in appropriate natural compounds as these elements are considered chemical analogs. In this respect, Se-fortified plants may lead to herbivory toxicity not only via a direct effect of inorganic derivatives and Se-containing amino acids, but also via the production of Se analogs of allicin, mono-, di- and tri-sulfides. The highest efficiency in Se biofortification is recorded for plants that are Se accumulators, which include Allium, Brassica species and garlic in particular [17].

Contrary to Se and S compounds, Si causes plant mechanical protection, which also causes toxicity or repellant activity against herbivories, such as: the formation of additional trichomes, an increase in wax accumulation on the leaves' surfaces and an abrasiveness increase in plant tissues, resulting in a reduction in palatability and digestibility for herbivores $[107,108]$.

The strongest beneficial effect of $\mathrm{Si}$ supplementation is recorded in plant $\mathrm{Si}$ accumulators belonging predominantly to the Poaceae family, while Brassica and Allium representatives (typical accumulators of $S$ and Se) are known to be non-Si accumulators [109].

Furthermore, the protective effects of the three mentioned supplements relate to the intensive emission of volatiles from the plant tissue of treated plants: di- and trimethyl selenides for Se, allicine and other mono- di- and tri-sulfides from garlic, and herbivoreinduced plant volatiles upon Si supplementation. While the first two ones show repellent properties against herbivories, silicon causes biochemical changes in plants, where volatile production intensifies the attraction of herbivory animals [52].

The protection against herbivories and the growth stimulation effect of all three preparations relate to hormonal activity. Supplementation of Se and Si induces intensive hormonal changes in plants. Se actively affects the production of auxins, gibberellins, jasmonic (JA) and salicylic (SA) acids and ethylene (ET) [110]. Silicon supplementation results in changes in JA, SA, ET and auxins' biosynthesis [59]. On the contrary, the growth stimula- 
tion effect of garlic extracts is closely connected to their high content of phytohormones: SA, auxins and gibberellins [111].

Furthermore, all these treatments for plants' protection against herbivories are closely connected with the intensification of plant antioxidant status, either directly (Se and S antioxidant properties) or indirectly, improving the production of natural antioxidants.

The attractiveness of $\mathrm{Se}, \mathrm{Si}$ and garlic extracts' utilization relates to the multiplicity of their beneficial effects, including pest management, protection against abiotic stress and an increase in crop yield and nutritional quality (Figure 6).

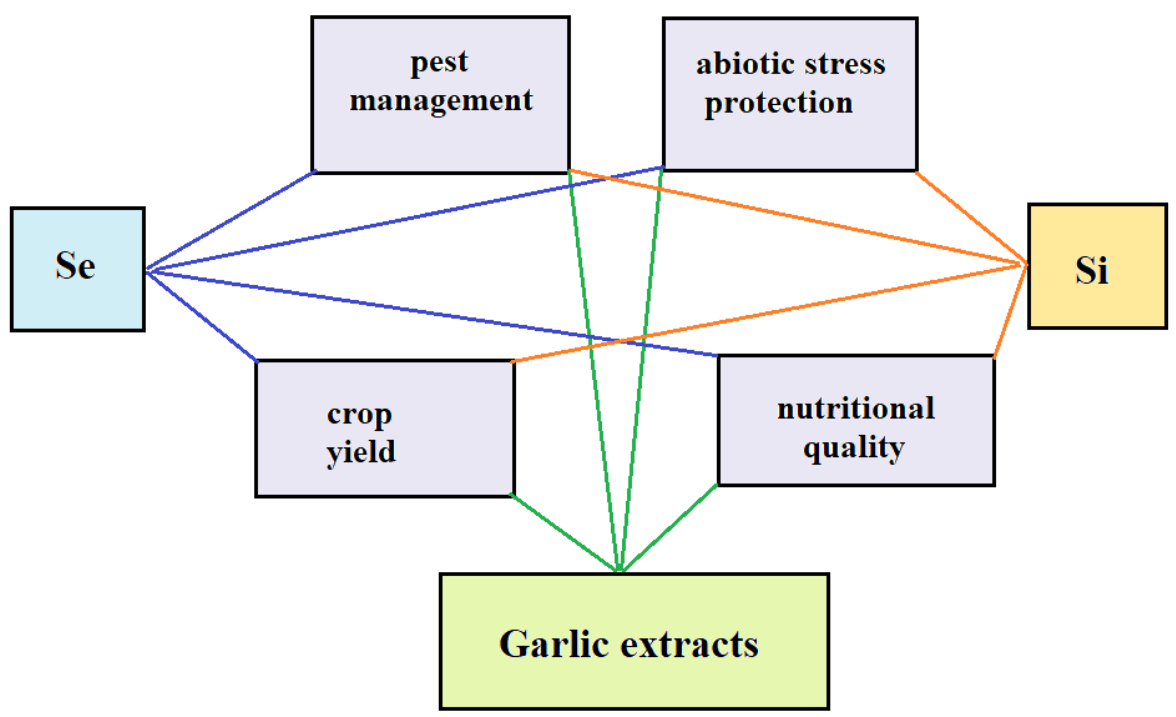

Figure 6. Beneficial effects of Se and Si compounds, and garlic extracts' utilization.

In this respect, the development of appropriate preparations is highly significant. To date, no appropriate registered products with active ingredients derived from garlic, selenium and silicon are known. Such a situation is connected with the complexity of Se, Si and garlic extracts' interaction with plants and insect pests, highlighting the necessity to find optimal concentrations that are sufficient to both demonstrate protection against pests and avoid toxicity. Notably, the beneficial protective effects of Se, Si and garlic extracts against insect pests are not ubiquitous and greatly depend on the plant and insect species, stage of pest development and supplement concentration. Indeed, silicic acid application resulted in the most pronounced protective effect against armyworms at the early time point in soybean and at early and late time points in maize [67]. Granite dust utilization was shown to be effective in the protection of lily but not squash and cabbage plants [66].

Theoretically, the supplementation of plants with selenium should result in variable protective effects against herbivorous pests, due to both variations in different Se chemical forms in fortified plants and differences in these compounds' toxicity to pests. At present, in most cases, we are not able to evaluate the composition of Se chemical derivatives present in plants upon Se supplementation.

As for garlic extract utilization, a serious problem exists in standardizing the preparations, whose activity will depend either on the concentration used or the chemical composition of garlic cloves. The allelopathic effect of garlic has been intensively studied [112,113] and an increase in extract concentration may lead to plant growth inhibition.

Taking into account the species differences in plants/insects' responses to $\mathrm{Se}, \mathrm{Si}$ and garlic extract supply, further investigations will be performed on this topic.

Notably, to date, the joint application of Se, Si and garlic extracts has never been used in pest management. Literature reports indicate that this approach may become especially beneficial, providing a growth stimulation effect, improving crops' quality and protecting plants against biotic and abiotic stresses. Joint supplementation of plants with Se and Si 
is known to be highly efficient in increasing plants' tolerance to abiotic stresses [114-118] and improving yields [119]. Unfortunately, no data are available concerning the efficiency of plants' protection against insect pests under joint Se and Si treatments. The joint application of garlic extracts with Se and Si compounds, both for plant growth and development and pest management, is extremely attractive, but such an approach needs special investigations.

\section{Conclusions}

Global economic crisis and climate changes indicate the need for urgent decisions aimed to ecological equilibrium restoration, the utilization of highly efficient and safe methods of both plant protection against herbivories, without any harmful effect either on human health or on the environment, and plant growth stimulation. The present review covers three possible strategies to address the mentioned issues, and their practical application will promote sustainable agricultural development. Further investigations should unveil the interactions of $\mathrm{Se}, \mathrm{Si}$ and garlic extract with plants and insect pests, which show remarkable complexity, and the connected effects of climate and soil, the genetic peculiarities of plants and different biologically active derivatives. However, the broad possibilities of Se, Si and garlic extracts' application, both for plant protection against pests and growth stimulation, suggest the necessity for the commercial production of appropriate supplements to successfully convert the mentioned innovative approaches into agricultural practice.

Author Contributions: Conceptualization, V.Z., M.F. and G.C.; formal analysis, V.Z. and M.A.; investigation, N.G., L.S., M.A., A.S. and V.Z.; methodology, N.G., L.S. and S.S.; supervision, V.Z., A.S. and S.S.; validation, G.C.; draft manuscript writing, N.G., S.S. and M.F.; manuscript revision and final editing, N.G., L.S., M.F. and G.C. All authors have read and agreed to the published version of the manuscript.

Funding: This research received no external funding.

Institutional Review Board Statement: Not applicable.

Informed Consent Statement: Not applicable.

Data Availability Statement: Not applicable.

Acknowledgments: The authors gratefully acknowledge Alexander Bogdanov and Andrew Yuriev for providing garlic from commercial cultivation.

Conflicts of Interest: The authors declare no conflict of interest.

\section{References}

1. Abass, A.B.; Ndunguru, G.; Mamiro, P.; Alenkhe, B.; Mlingi, N.; Bekunda, M. Post-harvest food losses in a maize-based farming system of semi-arid savannah area of Tanzania. J. Stored Prod. Res. 2014, 57, 49-57. [CrossRef]

2. Tapondjou, L.; Adler, C.; Bouda, H.; Fontem, D. Efficacy of powder and essential oil from Chenopodium ambrosioides leaves as post-harvest grain protectants against six-stored product beetles. J. Stored Prod. Res. 2002, 38, 395-402. [CrossRef]

3. Kumar, D.; Kalita, P. Reducing Postharvest Losses during Storage of Grain Crops to Strengthen Food Security in Developing Countries. Foods 2017, 6, 8. [CrossRef]

4. Singh, I.K.; Singh, A. Plant-Pest Interactions: From Molecular Mechanism to Chemical Ecology; Springer: Berlin/Heidelberg, Germany, 2021. [CrossRef]

5. Hamann, E.; Blevins, C.; Franks, S.J.; Jameel, M.; Anderson, J.T. Climate change alters plant-herbivore interactions. New Phytol. 2021, 229, 1894-1910. [CrossRef] [PubMed]

6. Skendžić, S.; Zovko, M.; Živkovi'c, I.P.; Leši'c, V.; Lemi' 'c, D. The impact of climate change on agricultural insects pests. Insects 2021, 12, 440. [CrossRef]

7. Stankovic, S.; Kostic, M.; Kostic, I.; Krnjajic, S. Practical Approaches to Pest Control: The Use of Natural Compounds. In Pests, Weeds and Diseases in Agricultural Crop and Animal Husbandry Production; IntechOpen: London, UK, 2020. [CrossRef]

8. War, A.R.; Paulraj, M.G.; Ahmad, T.; Buhroo, A.A.; Hussain, B.; Ignacimuthu, S.; Sharma, H.C. Mechanism of plant defense against insect herbivores. Plant Signal Behav. 2012, 7, 1306-1320. [CrossRef]

9. Mitchell, C.; Brennan, R.M.; Graham, J.; Karley, A.J. Plant defense against herbivorous pests: Exploiting resistance and tolerance Traits for sustainable crop production. Front. Plant Sci. 2016, 7, 1132. [CrossRef] [PubMed] 
10. Schiavon, M.; Nardi, S.; dalla Vecchia, F.; Ertani, A. Selenium biofortification in the 21st century: Status and challenges for healthy human nutrition. Plant Soil 2020, 453, 245-270. [CrossRef]

11. Kieliszek, M.; Bano, I.; Zare, H. A Comprehensive Review on Selenium and Its Effects on Human Health and Distribution in Middle Eastern Countries. Biol. Trace Elem. Res. 2021. [CrossRef]

12. Golubkina, N.A.; Kharchenko, V.A.; Caruso, G. Selenium: Prospects of functional food production with high antioxidant activity in Reference Series in Phyto-chemistry. In Plant Antioxidants and Health; Ekiert, H., Ramawat, K.G., Arora, J., Eds.; Elsevier: Amsterdam, Switzerland, 2021.

13. Kieliszek, M. Selenium-Fascinating Microelement, Properties and Sources in Food. Molecules 2019, 24, 1298. [CrossRef]

14. Zhang, L.; Liu, Y. Potential interventions for novel coronavirus in China: A systematic review. J. Med. Virol. 2020, 92, 479-490. [CrossRef] [PubMed]

15. Alfthan, G.; Eurola, M.; Ekholm, P.; Venäläinen, E.R.; Root, T.; Korkalainen, K.; Hartikainen, H.; Salminene, P.; Hietaniemi, V.; Aspila, P.; et al. Effects of nationwide addition of selenium to fertilizers on foods, and animal and human health in Finland: From deficiency to optimal selenium status of the population. J. Trace Elem. Med. Biol. 2015, 31, 142-147. [CrossRef] [PubMed]

16. Kovalsky, Y.G.; Golubkina, N.A.; Papazyan, T.T.; Senkevich, O.A. The human selenium status of Khabarovsk land population 2018. Trace Elem. Med. 2019, 20, 45-53. (In Russian) [CrossRef]

17. Gupta, M.; Gupta, S. An Overview of Selenium Uptake, Metabolism, and Toxicity in Plants. Front. Plant Sci. 2017, 7, 2074. [CrossRef] [PubMed]

18. Jensen, P.D.; Rivas, M.D.; Trumble, J.T. Developmental responses of a terrestrial insect detritivore, Megaselia scalaris (Loew) to four selenium species. Ecotoxicology 2005, 14, 313. [CrossRef]

19. Trumble, J.T.; Kund, G.S.; White, K.K. Influence of form and quantity of selenium on the development and survival of an insect herbivore. Environ. Pollut. 1998, 101, 175-182. [CrossRef]

20. Vickerman, D.B.; Trumble, J.T. Feeding preferences of Spodoptera exigua in response to form and concentration of selenium. Arch. Insect Biochem. Physiol. 1999, 42, 64-73. [CrossRef]

21. Mogren, C.L.; Trumble, J.T. The ipacts of metals and metalloids on insect behabior. Entomol. Exp. Applicata. 2010, 135, 1-17. [CrossRef]

22. Vickerman, D.B.; Shannon, M.C.; Bañuelos, G.S.; Grieve, C.M.; Trumble, J.T. Evaluation of Atriplex lines for selenium accumulation, salt tolerance and suitability for a key agricultural insect pest. Environ. Pollut. 2002, 120, 463-473. [CrossRef]

23. Vickerman, D.B.; Trumble, J.T. Biotransfer of selenium: Effects on an insect predator, Podisus maculiventris. Ecotoxicology 2003, 12, 497-504. [CrossRef]

24. Zhou, C.; Li, D.; Shi, X.; Zhang, J.; An, Q.; Wu, Y.; Kang, L.; Li, J.-Q.; Pan, C. Nanoselenium Enhanced Wheat Resistance to Aphids by Regulating Biosynthesis of DIMBOA and Volatile Components. Agric. Food Chem. 2021, 69, 14103-14114. [CrossRef]

25. Golubkina, N.; Moldovan, A.; Kekina, H.; Kharchenko, V.; Sekara, A.; Vasileva, V.; Skrypnik, L.; Tallarita, A.; Caruso, G. Joint Biofortification of Plants with Iodine and Selenium: A New Field of Discoveries. Plants 2021, 10, 1352. [CrossRef] [PubMed]

26. Pilon-Smits, E.A.H. On the ecology of selenium accumulation in pants. Plants 2019, 8, 197. [CrossRef] [PubMed]

27. Freeman, J.L.; Quinn, C.F.; Lindblom, S.D.; Klamper, E.M.; Pilon-Smits, E.A.H. Selenium protects the hyperaccumulator Stanleya pinnata against black-tailed prairie dog herbivory in native seleniferous habitats. Am. J. Bot. 2009, 96, 1075-1085. [CrossRef] [PubMed]

28. El-Mehdawi, A.F.; Pilon-Smits, E.A.H. Ecological aspects of plant selenium hyperaccumulation. Plant Biol. 2012, 14, 1-10. [CrossRef]

29. Mechora, Š.; Ugrinović, K. Can Plant-Herbivore Interaction be affected by Selenium? Austin J. Environ. Toxicol. $2015,1,5$.

30. Moxon, A.L. Selenium: Its occurrence in the rocks and soils, absorption by plants, toxic action in animals, and possible essential role in animal nutrition. In Trace Elements: Proceedings of the Conference, Agricultural Experiment Station, Wooster, Ohio, 14-16 October 1957; Lamb, C.A., Bentley, O.G., Beattie, J.M., Eds.; Academic Press: New York, NY, USA, 1958; pp. $175-191$.

31. Hanson, B.; Lindblom, S.D.; Loeffler, M.L.; Pilon-Smits, E.A.H. Selenium protects plants from phloem-feeding aphids due to both deterrence and toxicity. New Phytol. 2004, 162, 655-662. [CrossRef] [PubMed]

32. Hanson, B.; Garifullina, G.F.; Lindblom, S.D.; Wangeline, A.; Ackley, A.; Kramer, K.; Norton, A.P.; Lawrence, C.B.; Pilon-Smits, E.A.H. Selenium accumulation protects Brassica juncea from invertebrate herbivory and fungal infection. New Phytol. 2003, 159, 461-469. [CrossRef]

33. Freeman, J.L.; Lindblom, S.D.; Quinn, C.F.; Fakra, S.; Marcus, M.A.; Pilon-Smits, E.A. Selenium accumulation protects plants from herbivory by Orthoptera via toxicity and deterrence. New Phytol. 2007, 175, 490-500. [CrossRef]

34. Golubkina, N.; Sheshnitsan, S.; Kapitalchuk, M. Ecological Importance of Insects in Selenium Biogenic Cycling. Int. J. Ecol. 2014, 2014, 835636. [CrossRef]

35. Mechora, S. Selenium as a Protective Agent Against Pests: A Review. Plants 2019, 8, 262. [CrossRef]

36. Prins, C. Effect of Elevated Plant Selenium Levels on Reproduction and Root-Nematode Interaction. Master's Thesis, Colorado State University, Fort Collins, CO, USA, 2011.

37. Mechora, Š.; Placido Torres, D.; Bruns, R.E.; Škof, M.; Ugrinović, K. Effect of selenium treated broccoli on herbivory and oviposition preferences of Delia radicum and Phyllotreta spp. Sci. Hortic. 2017, 225, 445-453. [CrossRef]

38. Golubkina, N.; Skryabin, K. Anomalous accumulation of selenium by genetically modified potato, stable to Colorado beetle. J. Food Comp. Anal. 2010, 23, 190-193. [CrossRef] 
39. Quinn, C.F.; Freeman, J.L.; Galeas, M.L.; Klamper, E.M.; Pilon-Smits, E.A.H. The role of selenium in protecting plants against prairie dog herbivory: Implications for the evolution of selenium hyperaccumulation. Oecologia 2008, 155, 267-275. [CrossRef] [PubMed]

40. Quinn, C.F.; Freeman, J.L.; Reynolds, R.J.B.; Cappa, J.J.; Fakra, S.C.; Marcus, M.A.; Lindblom, S.D.; Quinn, E.K.; Bennett, L.E.; Pilon-Smits, E.A.H. Selenium hyperaccumulation offers protection from cell disruptor herbivores. BMC Ecol. 2010, 10, 19. [CrossRef] [PubMed]

41. Javeed, H.M.R.; Qamar, R.; Zamir, S.I.; Atique-ur-Rehman; Nawaz, F.; Faheem, M.M.; Ali, M.; Rehman, A.; Farooq, A.; Zakir, A. Selenate uptake through roots improves the tolerance to cell distuptors and fungal infection in Canola seedlings after exogenous selenium application. Pak. J. Agric. Sci. 2019, 56, 329-337. [CrossRef]

42. Hogan, G.R.; Razniak, H.G. Selenium-induced mortality and tissue distribution studies in Tenebrio molitor (Coleoptera: Tenebrionidae). Environ. Entomol. 1991, 20, 790-794. [CrossRef]

43. Popham, H.J.R.; Shelbya, K.S.; Popham, T.W. Effect of dietary selenium supplementation on resistance to baculovirus infection. Biol. Control 2005, 32, 419-426. [CrossRef]

44. Kastori, R.; Kadar, I. Effect of Selenium, Molybdenum and Zinc on Seedling Growth and Frequency of Grain Weevil (Sitophilus granarius) in Triticale grains. Pestic. I Fitomedicina 2009, 24, 133-138. [CrossRef]

45. Quinn, C.F.; Prins, C.N.; Freeman, J.L.; Gross, A.M.; Hantzis, L.J.; Reynolds, R.J.B.; Yang, S.; Covey, P.A.; Bañuelos, G.S.; Pickering, I.J.; et al. Selenium accumulation in flowers and its effects on pollination. New Phytol. 2011, 192, 727-737. [CrossRef]

46. Alburaki, M.; Smith, K.D.; Adamczyk, J.; Karim, S. Interplay between Selenium, selenoprotein genes, and oxidative stress in honey bee Apis mellifera L. J. Insect Physiol. 2019, 117, 103891. [CrossRef]

47. Luyckx, M.; Hausman, J.-F.; Lutts, S.; Guerriero, G. Silicon and Plants: Current Knowledge and Technological Perspectives. Front. Plant Sci. 2017, 8, 411. [CrossRef]

48. Ma, J.F. Role of silicon in enhancing the resistance of plants to biotic and abiotic stresses. Soil Sci. Plant Nutr. 2004, 50, 11-18. [CrossRef]

49. Liang, Y.; Nikolic, M.; Belanger, R.; Gong, H.; Song, A. Silicon and insect pest resistance. In Silicon in Agriculture; Springer: Berlin, Germany, 2015; pp. 197-207. [CrossRef]

50. Hou, M.L.; Han, Y.Q. Si-mediated rice plant resistance to the Asiatic rice borer: Effects of silicon amendment and rice varietal resistance. J. Econ. Entomol. 2010, 103, 1412-1419. [CrossRef]

51. Dias, P.A.S.; Sampaio, M.V.; Rodrigues, M.P.; Korndorfer, A.P.; Oliveira, R.S.; Ferreira, S.E.; Korndörfer, G.H. Induction of resistance by silicon in wheat plants to alate and apterous morphs of Sitobion avenae (Hemiptera: Aphididae). Environ. Entomol. 2014, 43, 949-956. [CrossRef]

52. Leroy, N.; de Tombeur, F.; Walgraffe, Y.; Cornélis, J.-T.; Verheggen, F.J. Silicon and Plant Natural Defenses against Insect Pests: Impact on Plant Volatile Organic Compounds and Cascade Effects on Multitrophic Interactions. Plants 2019, 8, 444. [CrossRef] [PubMed]

53. Singh, A.; Kumar, A.; Hartley, S.; Singh, I. Silicon: Its ameliorative effect on plant defense against herbivory. J. Exp. Bot. 2020, 71, 6730-6743. [CrossRef] [PubMed]

54. Islam, W.; Tayyab, M.; Khalil, F.; Hua, Z.; Huang, Z.; Chen, H.Y.H. Silicon-mediates plants defense against pathogens and insect pests. Pestic Biochem. Physiol. 2020, 168, 104641. [CrossRef]

55. Waterman, J.M.; Cibils-Stewart, X.; Cazzonelli, C.I.; Hartley, S.E.; Johnson, S.N. Short-term exposure to silicon rapidly enhances plant resistance to herbivory. Ecology 2021, 102, e03438. [CrossRef] [PubMed]

56. Johnson, S.N.; Hartley, S.E.; Ryalls, J.M.W.; Frew, A.; Hall, C.R. Targeted plant defense: Silicon conserves hormonal defense signaling impacting chewing but not fluid-feeding herbivores. Ecology 2021, 102, e03250. [CrossRef] [PubMed]

57. Thabet, A.F.; Boraei, H.A.; Galal, O.A.; El-Samahy, M.F.M.; Mousa, K.M.; Zhang, Y.Z.; Tuda, M.; Helmy, E.A.; Wen, J.; Nozaki, T. Silica nanoparticles as pesticide against insects of different feeding types and their non-target attraction of predators. Sci. Rep. 2021, 11, 14484. [CrossRef] [PubMed]

58. Rastogi, A.; Tripathi, D.K.; Yadav, S.; Chauhan, D.K.; Zivcak, M.; Ghorbanpour, M.; El-Sheery, N.I.; Brestic, M. Application of silicon nanoparticles in agriculture. 3 Biotech 2019, 9, 90. [CrossRef]

59. Bhat, J.A.; Rajora, N.; Raturi, G.; Sharma, S.; Dhiman, P.; Sanand, S.; Shivaraj, S.M.; Sonah, H.; Deshmukh, R. Silicon nanoparticles (SiNPs) in sustainable agriculture: Major emphasis on the practicality, efficacy and concerns. Nanoscale Adv. 2021, $3,4019$. [CrossRef]

60. He, W.; Yang, M.; Li, Z.; Qui, J.; Liu, F.; Qu, X.; Qiu, Y.; Li, R. High levels of silicon provided as a nutrient in hydroponic culture enhances rice plant resistance to brown planthopper. Crop Prot. 2015, 6, 20-25. [CrossRef]

61. Parrella, M.P.; Costamagna, T.P.; Kaspi, R. The addition of potassium silicate to the fertilizer mix to suppress Liriomyza leafminers attacking chrysanthemums. Acta Hortic. 2007, 747, 365-369. [CrossRef]

62. Reynolds, O.L.; Keeping, M.G.; Meyer, J.H. Silicon-augmented resistance of plants to herbivorous insects: A review. Ann. Appl. Biol. 2009, 155, 171-186. [CrossRef]

63. Alhousari, F.; Greger, M. Silicon and mechanism of plant resistance to insect pests. Plants 2018, 7, 33. [CrossRef]

64. Peixtot, M.L.; Moraes, J.C.; Silva, A.A.; Assis, F.A. Effect of silicon on the oviposition preference of Bemisia tabaci Biotype B (GENN.) (Hemiptera: Aleyrodidae) on bean (Phaseolus vulgaris L.) plants. Cienc. Agrotec. 2011, 35, 478-481. [CrossRef] 
65. Correa, R.S.B.; Moraes, J.C.; Auad, A.M.; Carvalho, G.A. Silicon and acibenzolar-S-methyl as resistance inducers in cucumber, against the whitefly Bemisia tabaci (Gennadius) (Hemiptera: Aleyrodidae) biotype B. Neotrop. Entomol. 2005, 34, 429-433. [CrossRef]

66. Faraone, N.; Hillier, N.K. Preliminary evaluation of a granite rock dust product for pest herbivore management in field conditions. Insects 2020, 11, 877. [CrossRef]

67. Acevedo, F.E.; Peiffer, M.; Ray, S.; Tan, C.-W.; Felton, G.V. Silicon-mediated enhancement of herbivore resistance in agricultural crops. Front. Plant Sci. 2021, 2, 631824. [CrossRef]

68. Assis, F.A.; Moraes, J.C.; Auad, A.M.; Coelho, M. The effects of foliar spray application of silicon on plant damage levels and components of larval biology of the pest butterfly Chlosyne lacinia saundersii (Nymphalidae). Int. J. Pest Manag. 2013, 59, 128-134. [CrossRef]

69. Frew, A.; Powell, J.R.; Hiltpold, I.; Allsopp, P.G.; Sallam, N.; Johnson, S.N. Host plant colonisation by arbuscular mycorrhizal fungi stimulates immune function whereas high root silicon concentrations diminish growth in a soil-dwelling herbivore. Soil Biol. Biochem. 2017, 112, 117-126. [CrossRef]

70. Assis, F.A.E.; Jair, C.M.; Luis, C.P.S.; Jonas, F.; Amanda, M.N.; Cristiana, S.A. Inducers of resistance in potato and its effects on defoliators and predatory insects. Rev. Colomb. Entomol. 2012, 38, 30-34.

71. Wang, J.; Xue, R.; Ju, X.; Yan, H.; Gao, Z.; Elzaki, M.E.A.; Hu, L. Silicon-mediated multiple interactions: Simultaneous induction of rice defense and inhibition of larval performance and insecticide tolerance of Chilo suppressalis by sodium silicate. Ecol. Evol. 2020, 10, 4816-4827. [CrossRef]

72. Yang, L.; Han, Y.Q.; Li, P.; Wen, L.; Hou, M. Silicon amendment to rice plants impairs sucking behaviors and population growth in the phloem feeder Nilaparvata lugens (Hemiltera: Delphacidae). Sci. Rep. 2017, 7, 1101. [CrossRef] [PubMed]

73. Costa, R.R.; Moraes, J.C.; DaCosta, R.R. Feeding behaviour of the greenbug Schizaphis graminum on wheat plants treated with imidacloprid and/or silicon. J. Appl. Entomol. 2011, 135, 115-120. [CrossRef]

74. Gomes, F.B.; Jair, C.D.M.; Custódio, D.D.S.; Márcio, M.G. Resistance induction in wheat plants by silicon and aphids. Sci. Agric. 2005, 62, 547-551. [CrossRef]

75. Bayan, L.; Koulivand, P.H.; Gorji, A. Garlic: A review of potential therapeutic effects. Avicenna J. Phytomed. 2014, 4, 1-14.

76. Fesseha, H.; Goa, E. Therapeutic value of garlic (Allium sativum): A Review. Adv. Food Technol. Nutr. Sci. Open J. 2019, 5, 107-117. [CrossRef]

77. Ali, M.; Ahmad, H.; Hayat, S.; Chani, M.I.; Aim, B.; Atif, M.J.; Wali, K.; Cgeng, A. Application of garlic allelochemisals improves frowth and induces defense repsonses in eggplant (Solanum melongena) against Verticillium dahliae. Ecotoxicol. Environ. Saf. 2021, 215, 112132. [CrossRef]

78. Wanyika, H.N.; Gachanja, A.N.; Kenji, G.M.; Keriko, J.M.; Mwangi, A.N. A rapid method based on UV spectrophotometry for quantitative determination of allicin in aqueous garlic extracts. J. Agric. Sci. Technol. 2011, 12, 77-84.

79. Blanchard, A.; Limache, F. Les Stimulateurs des Defenses Naturelles des Plantes (SDN). 2005. Available online: https://hal. archives-ouvertes.fr/hal-01857661/document (accessed on 15 October 2021).

80. Hardiansyah, M.Y.; Al Ridho, A.F. Nurhidayat The Effect of Garlic (Allium sativum) Extract Pesticides in Repelling Rice Eating Bird Pests. Indonesian J. Agric. Res. 2020, 3, 145-152. [CrossRef]

81. Sharaby, A.; El-Nojiban, A. Evaluation of some plant essential oils against the black cutworm Agrotis ipsilon. Glob. J. Adv. Res. 2015, 2, 701-711.

82. Kim, S.I.; Chae, S.H.; Youn, H.S.; Yeon, S.H.; Ahn, Y.J. Contact and fumigant toxicity of plant essential oils and efficacy of spray formulations containing the oils against B- and Q-biotypes of Bemisia tabaci. Pest Manag. Sci. 2011, 67, 1093-1099. [CrossRef] [PubMed]

83. Zhao, N.N.; Zhang, H.; Zhang, X.C.; Luan, X.B.; Zhou, C.; Liu, Q.Z.; Shi, W.P.; Liu, Z.L. Evaluation of acute toxicity of essential oil of garlic (Allium sativum) and its selected major constituent compounds against overwintering Cacopsylla chinensis (Hemiptera: Psyllidae). J. Econ. Entomol. 2013, 102, 1349-1354. [CrossRef]

84. Douri, A.; Bougdad, L.F.; Assobhei, O.; Moumni, M. Chemical composition and biological activity of Allium sativum essential oils against Callosobruchus maculatus. J. Environ. Sci. 2013, 3, 30-36. [CrossRef]

85. Hincapie, C.A.; Lopez, G.E.; Torres, R. Comparison and characterization of garlic (Allium sativum L.) bulbs extracts and their effect on mortality and repellency of Tetranychus urticae Koch (Acari: Tetranychidae). Chil. J. Agric. Res. 2008, 68, 317-327. [CrossRef]

86. Singh, S.; Singh, B.; Singh, A.P. Nematodes: A threat to sustainability of agriculture. Procedia Environ. Sci. 2015, 9, 215-216. [CrossRef]

87. Chaubey, M. Fumigant and contact toxicity of Allium sativum (Alliaceae) essential oil against Sitophilus oryzae L. (Coleoptera: Dryophthoridae). Entomol. Appl. Sci. Lett. 2016, 3, 43-48.

88. Vassiliou, V.A. Botanical Insecticides in Controlling Kelly's Citrus Thrips (Thysanoptera: Thripidae) on Organic Grapefruits. J. Econ. Entomol. 2011, 104, 1979-1985. [CrossRef]

89. Denloy, A.A. Bioactivity of Powder and Extracts from Garlic, Allium sativum L. (Alliaceae) and Spring Onion, Allium fistulosum L. (Alliaceae) against Callosobruchus maculatus F. (Coleoptera: Bruchidae) on Cowpea, Vigna unguiculata (L.) Walp (Leguminosae) Seeds. J. Enthomol. 2010, 2010, 958348. [CrossRef]

90. Al-Shuraym, L.A.M.; Al-Keridis, L.A.; Al-Dakhil, A.A.; Al-Qahtani, W.S. The impact of onion-garlic mixture to control of Rhynchophorus ferrugineus in Saudi Arabia. J. Saudi Soc. Agric. Sci. 2020, 19, 521-527. [CrossRef] 
91. Baidoo, P.K.; Mochiah, M.B. Comparing the Effectiveness of Garlic (Allium sativum L.) and Hot Pepper (Capsicum frutescens L.) in the Management of the Major Pests of Cabbage Brassica oleracea (L.). Int. Sustain. Agric. Res. 2016, 5, 83-91. [CrossRef]

92. González-Macedo, M.; Cabiro, L.N.; Rojas-Oropeza, M. Assessment of the ancestral use of garlic (Allium sativum) and nettle (Urtica dioica) as botanical insecticides in the protection of mesquite (Prosopis laevigata) seeds against bruchins. J. Plant Prot. Res. 2021, 61, 170-175. [CrossRef]

93. Rinaldi, S.; Casorri, L.; Masciarelli, E.; Beni, C. Prospects of using garlic extracts for pest control in sustainable agriculture. Fres. Environ. Bull. 2019, 28, 535-540.

94. Nwachukwu, I.D.; Asawalam, E.F. Evaluation of freshly prepared juice from garlic (Allium sativum L.) as a biopesticide against the maize weevil, Sitophilus zeamais (Motsch.) (Coleoptera: Curculionidae). J. Plant Prot. Res. 2014, 54, 132-138. [CrossRef]

95. Prowse, G.M.; Galloway, T.S.; Foggo, A. Insecticidal activity of garlic juice in two dipteran pests. Agric. For. Entomol. 2006, 8, 1-6. [CrossRef]

96. Park, I.K.; Choi, K.S.; Kim, D.H.; Choi, I.H.; Kim, L.S.; Bak, W.C.; Choi, J.W.; Shin, S.C. Fumigant activity of plant essential oils and components from horseradish (Armoracia rusticana), anise (Pimpinella anisum) and garlic (Allium sativum) oils against Lycoriella ingenua (Diptera: Sciaridae). Pest Manag. Sci. 2006, 62, 723-728. [CrossRef] [PubMed]

97. Macial, C.M.; Shikano, I.; Smirle, M.; Bradbury, R.; Isman, M.B. Evaluation of the toxicity of 17 essential oils against Choristoneura rosaceana (Lepidoptera: Tortricidae) and Trichoplusia. ni (Lepidoptera: Noctuidae). Pest Manag. Sci. 2010, 66, 1116-1121. [CrossRef]

98. Anwar, A.; Gould, E.; Tinson, R.; Groom, M.; Hamilton, C.J. Think Yellow and Keep Green-Role of Sulfanes from Garlic in Agriculture. Antioxidants 2017, 6, 3. [CrossRef] [PubMed]

99. Chang, Y.; Lee, S.-H.; Na, J.H.; Chang, P.-S.; Han, J. Protection of Grain Products from Sitophilus oryzae (L.) Contamination by Anti-Insect Pest Repellent Sachet Containing Allyl Mercaptan Microcapsule. J. Food Sci. 2017, 82, 2634-2642. [CrossRef]

100. Gagné, R.J. A Catalog of the Cecidomyiidae (Diptera) of the World; The Entomological Society of Washington: Washington, DC, USA, 2004

101. Harris, M.O.; Foster, S.P. "Gall Midges," in Pheromones of Non-Lepidopteran Insects Associated with Agricultural Plants; Hardie, J., Ed.; CAB International: Oxford, UK, 1999; pp. 27-49.

102. Stireman, J.O., III; Janson, E.M.; Carr, T.G.; Devlin, H.; Abbot, P. Evolutionary radiation of Asteromyia Carbonifera (Diptera: Cecidomyiidae) gall morphotypes on the goldenrod Solidago Altissima (Asteraceae). Biol. J. Linnean Soc. 2008, 95, 840-858. [CrossRef]

103. Mishima, M.; Sato, S.; Tsuda, K.; Yukawa, J. Sexual isolation between two known intraspecific populations of Hartigiola (Diptera: Cecidomyiidae) that induce leaf galls on upper and lower surfaces of Fagus crenata (Fagales: Fagaceae), indicating possible diversification into sibling species. Arthropod Biol. 2013, 107, 789-798. [CrossRef]

104. Yukawa, J.; Uechi, N.; Tokuda, M.; Sato, S. Radiation of gall midges (Diptera: Cecidomyiidae) in Japan. Basic Appl. Ecol. 2005, 6, 453-461. [CrossRef]

105. Keunen, E.; Peshev, D.; Vangronsveld, J.; Van Den Ende, W.; Cuypers, A. Plant sugars are crucial players in the oxidative challenge during abiotic stress: Extending the traditional concept. Plant Cell Environ. 2013, 36, 1242-1255. [CrossRef]

106. Hayat, S.H.; Ali, A.M.; Hayat, K.; Khan, M.A.; Cheng, Z. Aqueous Garlic Extract as a Plant Biostimulant Enhances Physiology, Improves Crop Quality and Metabolite Abundance, and Primes the Defense Responses of Receiver Plants. Appl. Sci. 2018, 8, 1505. [CrossRef]

107. Massey, F.P.; Hartley, S.E. Physical defenses wear you down: Progressive and irreversible impacts of silica on insect herbivores. J. Anim. Ecol. 2009, 78, 281-291. [CrossRef]

108. Frew, A.; Weston, L.A.; Reynolds, O.L.; Gurr, G.M. The role of silicon in plant biology: A paradigm shift in research approach. Ann. Bot. 2018, 121, 1265-1273. [CrossRef]

109. Shivaraj, S.M.; Mandlik, R.; Bhat, J.A.; Raturi, G.; Elbaum, R.; Alexander, L.; Tripathi, D.K.; Deshmukh, R.; Sonah, H. Outstanding Questions on the Beneficial Role of Silicon in Crop Plants. Plant Cell Physiol. PCAB 2021, 145, 1-15. [CrossRef]

110. Golubkina, N. Selenium Biorhythms and Hormonal Regulation Chapter 2 in Selenium: Sources, Functions and Health Effects; Aomori, C., Hokkaido, M., Eds.; Nova Science Pubishers Inc.: New York, NY, USA, 2012; pp. 33-74. ISBN 989-1-61942-061-8.

111. Elzaawely, A.A.; Ahmed, M.E.; Maswada, H.F.; Al-Araby, A.A.; Xuan, T.D. Growth traits, physiological parameters and hormonal status of snap bean (Phaseolus vulgaris L.) sprayed with garlic cloves extract. Arch. Agron. Soil Sci. 2018, 62, 1068-1082. [CrossRef]

112. Ding, H.; Ali, A.; Cheng, Z. An allelopathic role of garlic root exudares on regulation of carbohydrate metabolism in cucumber in a hydroponic co-culture systen. Plants 2020, 9, 45. [CrossRef] [PubMed]

113. El-Rokick Kowther, G.; El-Masry, R.R.; Ahmed, S.A.A.; Mohan, S.A.; Messiha, N.K. Allelopathic effects of Allium sativum cloves on growth and yield of Helianthus annuus plants associating Cyperus rotundus. Int. J. Environ. 2018, 7, 78-86.

114. Kleiber, T.; Borowiak, K.; Kosiada, T.; Bre's, W.; Ławniczak, B. Application of selenium and silicon to alleviate short-term drought stress in French marigold (Tagetes patula L.) as a model plant species. Open Chem. 2020, 18, 1468-1480. [CrossRef]

115. Shalaby, T.A.; Abd-Alkarim, E.; El-Aidy, F.; El-Samahy, H.; Sharaf-Eldin, M.; Taha, N.; El-Ramady, H.; Bayoumi, Y.; Reis, A.R. Nano-selenium, silicon and $\mathrm{H}_{2} \mathrm{O}_{2}$ boost growth and productivity of cucumber under combined salinity and heat stress. Ecotoxicol. Environ. Saf. 2021, 212, 111962. [CrossRef] [PubMed]

116. Zahedi, S.M.; Moharrami, F.; Sarikhani, S.; Padervand, M. Selenium and silica nanostructure-based recovery of strawberry plants subjected to drought stress. Sci. Rep. 2021, 10, 17672. [CrossRef] 
117. Guo, K.; Hu, A.; Wang, K.; Wang, L.; Fu, D.; Hao, Y.; Wang, Y.; Ali, A.; Adeel, M.; Rui, Y.; et al. Effects of spraying nano-materials on the absorption of metal(loid)s in cucumber. IET Nanobiotechnol. 2019, 13, 712-719. [CrossRef]

118. Badawy, S.A.; Zayed, B.A.; Bassiouni, S.M.A.; Mahdi, A.H.A.; Majrashi, A.; Ali, E.F.; Seleiman, M.F. Influence of Nano Silicon and Nano Selenium on Root Characters, Growth, Ion Selectivity, Yield, and Yield Components of Rice (Oryza sativa L.) under Salinity Conditions. Plants 2021, 10, 1657. [CrossRef]

119. Golubkina, N.; Moldovan, A.; Fedotov, M.; Kekina, H.; Kharchenko, V.; Folmanis, G.; Alpatov, A.; Caruso, G. Iodine and Selenium Biofortification of Chervil Plants Treated with Silicon Nanoparticles. Plants 2021, 10, 2528. [CrossRef] 